\title{
Estimation of Heterosis for Seed Yield and Its Attributing Traits in Linseed (Linum usitatissimum L.)
}

\author{
Namrata Dhirhi, Nandan Mehta and Satyapal Singh*
}

Department of Genetics and Plant Breeding, IGKV, Raipur-492 012, Chhattisgarh, India

*Corresponding author

\section{A B S T R A C T}

\begin{tabular}{|l|}
\hline Ke y w o r d s \\
Linseed, Heterosis, Line x \\
tester, ALA, SDG
\end{tabular}

Twenty hybrids of linseed generated by crossing of 5 lines and 4 testers in line $\times$ tester mating design were sown along with their nine parental lines to assess the extent of average heterosis over heterobeltiosis for seed yield and its component traits during Rabi, 2014-2015 and 2015-2016. This experiment was carried out at Research cum Instructional Farm, Department of Genetics and Plant Breeding, College of Agriculture, AICRP on Linseed, I.G.K.V., Raipur, Chhattisgarh. Among twenty hybrids, Sabour Yellow x Chambal which shows higher heterobeltiosis for multiple traits like days to $50 \%$ flowering, plant height $(\mathrm{cm})$, number of primary branches plant ${ }^{-1}$, number of secondary branches ${ }^{-1}$, number of capsules plant ${ }^{-1}$, Hence, the hybrids having high heterosis can be effectively used for isolating transgressive segregants, which will increase the frequency of desirable genes for yield component traits along with economic traits in linseed.

\section{Introduction}

Linseed (Linum usitatissimum L.) is one of the oldest crops under cultivation. It belongs to the family Linaceae and is presumed to be originated in southwest Asia particularly in India (Vavilov, 1935; Richharia, 1962). The linseed oil is rich in fatty acids alpha linolenic acid (ALA) an essential Omega-3 fatty acid and lignin oligomers accounting for $57 \%$ of total fatty acids in its biochemical composition (Reddy et al., 2013).

Around the globe linseed crop occupies an area of 22.70 lakh ha yielding out 22.39 lakh tones having an average productivity of 986 $\mathrm{kg} / \mathrm{ha}$. In India, it is grown in an area of 29210 ha with production and productivity being 141200 tones and $484 \mathrm{~kg} /$ ha respectively. India ranks second in area after Canada which is almost equivalent to China which so far occupied the second slot in world area by the crop. Our national production slides to third place after Canada and China. India contributes about $14.89 \%$ and $6.56 \%$ to world area and production respectively. In India, the crop is mainly cultivated in the states like Madhya Pradesh, Chhattisgarh, Uttar Pradesh, Maharashtra, Bihar, Odisha, Jharkhand, Karnataka and Assam accounting for more than 97 per cent of the total area. Chhattisgarh is one of the important linseed growing states of India, which account 26200 hectares area and 1100 tonnes production with productivity of $424 \mathrm{~kg} / \mathrm{ha}$ (Annual Report, Linseed 2014- 
15). The average productivity is very low as compared to other countries where it is grown. Hence, there is an urgent need to increase the productivity by breaking the present yield barrier and developing hybrids with high yield potential (Ramesh et al., 2013 and Jhajharia et al., 2013).

Industrial oil and mostly, 80 percent of oil is used for paints, varnishes, a wide range of coating oils, linoleum, pad and printing inks, oil cloth, patent leather, enamels, stickers, tarpaulins leather and soap industries. Linseed contains about 33 to $45 \%$ oil and $24 \%$ crude protein which is one of the oldest commercial oils used for various purposes. Recently it has gained a new interest in the emerging market of functional food due to its high content of fatty acids, alpha linolenic acid (ALA), an essential Omega 3 fatty acid and lignan content or SDG (seco isolariciresinol diglucoside) which constitute about $57 \%$ of total fatty acids in linseed (Morris, 2005). Almost every part of its plant is commercially utilized, either directly or after processing. New industrial uses of both the linseed oil and the fibres of oilseed flax also will increase the demand for this multi-use oilseed crop.

The study on the magnitude of heterosis would help in identifying promising cross combinations for exploitation of heterosis for genetic improvement of quantitative traits and genetic information on heterosis is useful for developing breeding strategies to meet the demands of increased population. It is necessary to have detailed information about the desirable parental combination in any breeding program which can reflect a high degree of heterotic response. It has become a common practice of the plant breeder working with crop plants to obtain genetic information of the diverse breeding material from line $\mathrm{x}$ tester technique developed by Kempthorne (1957). Therefore, heterotic studies can provide the basis for the exploitation of valuable hybrid combinations in future breeding programs as earlier reported by Pali and Mehta (2014); Reddy et al., (2013); Ratna parkhi et al., (2005); Sharma et al., (2005). The present investigation was undertaken with an objective to measure the magnitude of heterosis in hybrids for seed yield and associated traits in linseed.

\section{Materials and Methods}

The experimental material comprised of five promising linseed lines having higher yield and better agronomic characters viz., RLC-92, Sagar Local, Sabour Yellow, Sakoor, and Neela were crossed with four different testers having broad genetic base and wide adaptability viz. T-397, Chambal, Neelam and Shekhar. The 20 hybrids were raised, along with the respective parents in a randomized complete block design with three replications during Rabi, 2014-2015 and 2015-2016.

This experiment was carried out at Research cum Instructional Farm, Department of Genetics and Plant Breeding, College of Agriculture, AICRP on Linseed, I.G.K.V., Raipur, Chhattisgarh. The hybrids and parents were sown in a single row of 3 meter length with inter and intra-row spacing of $30 \mathrm{~cm}$ and $10 \mathrm{~cm}$, respectively. All the recommended agronomical package of practices and plant protection measures were followed timely to raise a good crop.

Five plants were selected randomly in each replication from each parent and hybrid and observations were recorded for ten quantitative characters viz., days to 50\% flowering, days to maturity, plant height, Number of primary branches plant ${ }^{-1}$, Number of secondary branches plant ${ }^{-1}$, Total number of branches plant ${ }^{-1}$, number of capsules plant ${ }^{-1}$, number of seeds capsules-1, 1000 seed weight and seed yield plant ${ }^{-1}$. The mean values were calculated and used for statistical analysis. 
The data recorded on $\mathrm{F}_{1} \mathrm{~s}$ were analyzed as per the method suggested by Kempthorne (1957). Heterosis over better parent for all the ten characters was estimated.

\section{Results and Discussion}

The study of heterosis provide only the percent increase of $F_{1}$ over the mid or better parent or best check, thus helps in identifying the best crosses but fails to identify the possible causes for superiority of hybrids. It is an effective tool in improving the yield and component traits of different crop species. The heterosis breeding has been extensively utilized in improving yield particularly in linseed crop. The heterobeltiosis for seed yield and its components in linseed are presented in Table 1.

\section{Days to $50 \%$ flowering}

For this trait, negative heterosis is of main interest to the breeder because it is always desirable to incorporate earliness, hence more attention was given towards negative heterosis. The average heterosis of this trait ranged from -11.0 (Sabour Yellow x Shekhar) to 3.7 (Sakoor x Shekhar).

Thirteen out of twenty hybrids showed significant relative heterosis and eight hybrids showed negative heterosis and five hybrids showed positive heterosis.

The top hybrid showed significant negative heterosis for this trait were RLC-92 x T-397, Sakoor x Neelam, Neela x T-397, Neela x Neelam, Neela x Chambal, SagarLocal x T397, Sabour Yellow x Chambal and Sabour Yellow x Shekhar. The heterobeltiosis ranged from -11.2 (Sabour Yellow x Shekhar) to 1.0 (Sagar Local x Neelam). Twelve hybrids out of twenty crosses showed significant negative heterosis.

\section{Days to maturity}

Like days to flowering, one is always interested to have early maturing strains, hence for this trait also negative heterosis is of interest. Therefore, it becomes important to select cross combinations having significant negative heterosis. The average heterosis for this character ranged from -3.6 (Neela $\mathrm{x}$ Neelam) to 2.7 (Sakoor x Chambal). Fourteen hybrids out of twenty crosses showed nonsignificant negative heterosis and six hybrid showed non-significant positive heterosis.

The heterobeltiosis ranged from -3.8 (Neela $\mathrm{x}$ Neelam) to 0.6(Sakoor x T-397, Sakoor $\mathrm{x}$ Chambal, Neela x Shekhar).Fifteen hybrid showing non-significant negative heterosis and only five hybrid sowing non-significant positive heterosis. None of the crosses were found significant negative and significant positive heterosis for this trait.

\section{Plant height (cm)}

For this trait respective range of average heterosis varied from -19.0 (SagarLocal x Neelam) to 41.8 (Sabour Yellow $\mathrm{x}$ Chambal).Six hybrid out of twenty crosses showed significant heterosis of which one hybrid showed significant negative heterosis and four hybrid showed significant positive heterosis. The heterobeltiosis ranged from 28.0 (Sagar Local x Neelam) to 37.5 (Sabour Yellow x T-397). Among six hybrids showing significant heterobeltiosis, two hybrids viz. RLC-92 x Shekhar and Sagar Local x Neelam showed significant negative heterosis for this trait and four hybrids exhibited significant positive heterobeltiosis.

\section{Number of primary branches plant ${ }^{-1}$}

Number of primary branches plant ${ }^{-1}$ had great bearing on the total productivity. None of the hybrids showed negative heterosis. 
Table.1 Heterobeltiosis (\%) for seed yield and its components in linseed during 2015-16 at Raipur C.G.

\begin{tabular}{|c|c|c|c|c|c|c|c|c|c|c|c|}
\hline \multirow[t]{2}{*}{$\begin{array}{l}\text { S. } \\
\text { No. }\end{array}$} & \multirow[t]{2}{*}{ Crosses } & \multicolumn{2}{|c|}{ Days to $50 \%$ flowering } & \multicolumn{2}{|c|}{ Days to maturity } & \multicolumn{2}{|c|}{ Pplant height(cm) } & \multicolumn{2}{|c|}{$\begin{array}{l}\text { Number of primary } \\
\text { branches plant }^{-1}\end{array}$} & \multicolumn{2}{|c|}{$\begin{array}{l}\text { Number of secondary } \\
\text { branches plant }^{-1}\end{array}$} \\
\hline & & $\mathrm{AH} \%$ & $\mathrm{HB} \%$ & $\mathrm{AH} \%$ & $\mathrm{HB} \%$ & $\mathrm{AH} \%$ & $\mathrm{HB} \%$ & $\mathrm{AH} \%$ & $\mathrm{HB} \%$ & $\mathrm{AH} \%$ & $\mathrm{HB} \%$ \\
\hline 1 & RLC-92 xT-397 & $-3.32 * *$ & $-7.05^{* *}$ & -1.60 & -1.69 & $28.28 * *$ & $20.19 *$ & $113.33 *$ & 60.00 & -7.32 & -25.49 \\
\hline 2 & RLC-92 x Neelam & $3.02 * *$ & 0.69 & 0.67 & 0.34 & -4.73 & -4.73 & 78.95 & 70.00 & 22.89 & 0.00 \\
\hline 3 & RLC-92 x Chambal & $3.48 * *$ & -0.67 & -0.34 & -0.84 & 9.88 & 0.00 & 60.00 & 33.33 & 0.00 & -5.88 \\
\hline 4 & RLC-92 x Shekhar & -0.70 & $-3.75 * *$ & 0.34 & 0.34 & -8.15 & $-21.77 *$ & 29.41 & 10.00 & -5.13 & -27.45 \\
\hline 5 & Sakoor x T-397 & $3.57 * *$ & $-2.68 * *$ & 2.31 & 0.67 & 11.24 & 7.22 & $220.00 * *$ & $140.00 * *$ & 60.56 & 42.50 \\
\hline 6 & Sakoor x Neelam & $-2.55^{*}$ & $-6.94 * *$ & -1.71 & -3.52 & -8.01 & -16.72 & 36.84 & 30.00 & $69.44 *$ & 52.50 \\
\hline 7 & Sakoor x Chambal & $2.32 * *$ & -4.01 & 2.73 & 0.67 & 12.96 & 12.31 & 60.00 & 33.33 & -3.53 & -8.89 \\
\hline 8 & Sakoor x Shekhar & $3.78 * *$ & -1.71 & 0.86 & -0.68 & -5.00 & -11.28 & 76.47 & 50.00 & 25.37 & 5.00 \\
\hline 9 & Neela x T-397 & $-7.59 * *$ & -8.05 & -0.67 & -0.67 & 1.49 & -6.13 & $180.00 *$ & 180.00 & 83.67 & 45.16 \\
\hline 10 & Neela x Neelam & $-7.03 * *$ & $-8.14 * *$ & -3.62 & -3.86 & -2.33 & -3.68 & 100.00 & 55.56 & $112.00 *$ & 65.63 \\
\hline 11 & Neela x Chambal & $-5.05 * *$ & $-5.69 * *$ & -0.25 & -0.67 & -3.75 & -13.50 & $90.00 *$ & 26.67 & $80.95^{*}$ & 26.67 \\
\hline 12 & Neela x Shekhar & -0.34 & -0.68 & 0.76 & 0.67 & 11.11 & -6.44 & 116.67 & 85.71 & 95.56 & 62.96 \\
\hline$\overline{13}$ & Sagar Local x T-397 & $-1.89^{*}$ & $-4.03 * *$ & -0.33 & -1.16 & $29.25 * *$ & $22.02 *$ & $126.09 * *$ & 44.44 & $103.03 * *$ & $91.43 *$ \\
\hline 14 & Ssagar Local x Neelam & 1.57 & 1.04 & -1.75 & -2.32 & $-19.01 *$ & $-28.08 * *$ & $70.37 *$ & 27.78 & 22.39 & 17.14 \\
\hline 15 & Sagar Local x Chambal & -2.05 & $-4.35 * *$ & -0.75 & -1.16 & 12.65 & 9.62 & 15.15 & 5.56 & 5.00 & -6.67 \\
\hline 16 & Sagar Local x Shekhar & 1.38 & 0.00 & -0.75 & -1.66 & $27.51 *$ & 21.54 & $76.00 *$ & 22.22 & $83.87 *$ & 62.86 \\
\hline 17 & Sabour Yellow x T-397 & -2.70 & $-3.36^{* *}$ & -2.62 & -3.04 & $38.24 * *$ & $37.50 * *$ & $109.09 * *$ & 35.29 & 29.58 & 15.00 \\
\hline 18 & Sabour Yellow x Neelam & -3.09 & $-4.08 * *$ & -2.70 & -3.36 & -1.17 & -6.94 & $76.92 *$ & 35.29 & 33.33 & 20.00 \\
\hline 19 & Sabour Yellow x Chambal & $-2.19 *$ & $-3.01 * *$ & -2.19 & -3.01 & $41.85^{* *}$ & $36.79 * *$ & $68.75^{*}$ & $58.82^{*}$ & $97.65 * *$ & $86.67 * *$ \\
\hline 20 & Sabour Yellow x Shekher & $-11.07 * *$ & $-11.22 * *$ & -3.22 & -3.55 & 2.98 & -7.50 & $83.33^{*}$ & 29.41 & 25.37 & 5.00 \\
\hline
\end{tabular}

*,** Significant at $5 \%$ and $1 \%$ level, respectively 
Table.2 Heterobeltiosis (\%) for seed yield and its components in linseed during 2015-16 at Raipur C.G.

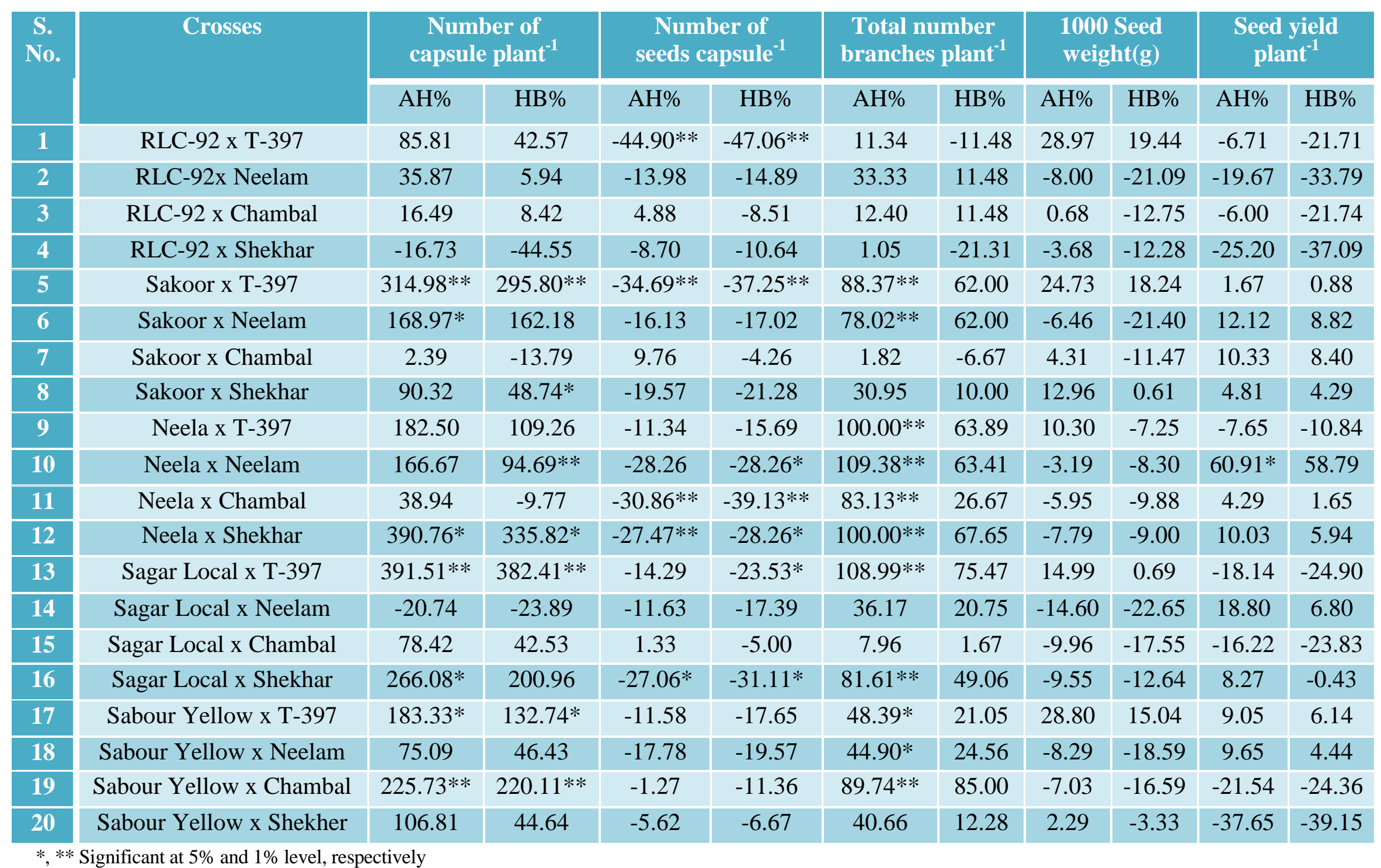


Table.3 List of top ranking cross combinations based on average heterosis and heterobeltiosis during 2015-16 Raipur, C.G.

\begin{tabular}{|c|c|c|c|}
\hline S. No. & Characters & Average heterosis (\%) & Heterobeltiosis (\%) \\
\hline 1 & $\begin{array}{l}\text { Days to } \\
\text { flowering }\end{array}$ & $\begin{array}{l}\text { RLC-92 x T-397,RLC-92 x Neelam, RLC-92 x Chambal, } \\
\text { Sakoor x Neelam, Sakoor x Chambal, Sakoor x Shekhar, } \\
\text { Neela x T-397.Neela x Neelam, Neela x Chambal, Sagar } \\
\text { Local x T-397,SabourYellow x Chambal, Sabour Yellow x } \\
\text { Shekhar }\end{array}$ & $\begin{array}{l}\text { RLC-92 x T-397,RLC-92 x Shekhar, Sakoor x T-397, } \\
\text { Sakoor x Neelam, Neela x Neelam, Neela x Chamble, } \\
\text { Sagar Local x T-397,SagarLocal x Chambal, Sabour } \\
\text { Yellow x T-397,SabourYellow x Neelam, Sabour } \\
\text { Yellow x Chambal, SabourYellow x Shekher }\end{array}$ \\
\hline 2 & $\begin{array}{l}\text { Plant height } \\
(\mathrm{cm})\end{array}$ & $\begin{array}{l}\text { RLC-92 x T-397, Sagar Local x T-397, Sagar Local x } \\
\text { Neelam, Sagar Local x Shekhar, Sabour Yellow x T-397, } \\
\text { SabourYellow x Shekhar }\end{array}$ & $\begin{array}{l}\text { RLC-92 x T-397,RLC-92 x Shekhar, Sagar Local x T- } \\
\text { 397, Sagar Local x Neelam, Sabour Yellow x T-397, } \\
\text { Sabour Yellow x Chambal }\end{array}$ \\
\hline 3 & $\begin{array}{l}\text { Number of } \\
\text { primary } \\
\text { branches } \\
\text { plant }^{-1}\end{array}$ & $\begin{array}{l}\text { RLC-92 x T-397,Sakoor x T-397, Neela x T-397,Neela x } \\
\text { Chambal, Sagar Local x T-397,Sagar Local x Neelam, } \\
\text { Sagar Local x Shekhar, SabourYellow x T- } \\
\text { 397,SabourYellow x Neelam, SabourYellow x Chambal, } \\
\text { Sabour Yellow x Shekhar }\end{array}$ & Sakoor x T-397, Sabour Yellow x Chambal \\
\hline 4 & $\begin{array}{l}\text { Number of } \\
\text { secondary } \\
\text { branches } \\
\text { plant }^{-1}\end{array}$ & $\begin{array}{l}\text { Sakoor x Neelam, Neela x Neelam, Neela x Chambal, } \\
\text { Sagar Local x T-397,Sagar Local x Shekhar, SabourYellow } \\
\text { x Chambal }\end{array}$ & Sagar Local x T-397, Sabour Yellow x Chambal \\
\hline 5 & $\begin{array}{l}\text { Number of } \\
\text { capsules } \\
\text { plant }^{-1}\end{array}$ & $\begin{array}{l}\text { Sakoor x T-397, Sakoor x Neelam, Neela x Shekhar, Sagar } \\
\text { Local x T-397, Sagar Local x Shekhar, SabourYellow x T- } \\
\text { 397, SabourYellow x Chambal }\end{array}$ & $\begin{array}{l}\text { Sakoor x T-397, Sakoor x Shekhar, Neela x Neelam, } \\
\text { Neela x Shekhar, Sagar Local x T-397, SabourYellow x } \\
\text { T-397, SabourYellow x Chambal }\end{array}$ \\
\hline 6 & $\begin{array}{l}\text { Number of } \\
\text { seeds } \\
\text { capsule }^{-1}\end{array}$ & $\begin{array}{l}\text { RLC-92 x T-397, Sakoor x T-397, Neela x Chambal, Neela } \\
\text { x Shekhar, Sagar Local x Shekhar }\end{array}$ & $\begin{array}{l}\text { RLC-92 x T-397, Sakoor x T-397, Neela x Neelam, } \\
\text { Neela x Chambal, Neela x Shekhar, Sagar Local x T- } \\
\text { 397, Sagar Local x Shekhar }\end{array}$ \\
\hline 7 & $\begin{array}{l}\text { Total } \\
\text { number of } \\
\text { branches } \\
\text { plant }^{-1}\end{array}$ & $\begin{array}{l}\text { Sakoor x T-397, Sakoor x Neelam, Neela x T-397, Neela x } \\
\text { Neelam, Neela x Chambal, Neela x Shekhar, Sagar Local x } \\
\text { T-397, Sagar Local x Shekhar, Sabour Yellow x T-397, } \\
\text { Sabour Yellow x Neelam, Sabour Yellow x Chambal }\end{array}$ & - \\
\hline 8 & $\begin{array}{l}\text { Seed yield } \\
\text { plant }^{-1}(\mathrm{~g})\end{array}$ & Neela x Neelam & - \\
\hline
\end{tabular}


The range of average heterosis for number of primary branches plant ${ }^{-1}$ was 220.0 (Sakoor $\mathrm{x}$ T-397) to 15.1 (Sagar Local $x$ Chambal). Eleven hybrids showed significant positive heterosis for this trait. The heterobeltiosis ranged from 180.0 (Neela $\mathrm{x} \mathrm{T}-397$ ) to 5.5 (Sagar Local x Chambal). Only two hybrids viz. Sakoor x T-397 and Sabour Yellow x Chambal showed significant positive heterobeltiosis.

\section{Number of secondary branches plant ${ }^{-1}$}

For this trait respective range of average heterosis varied from-7.3 (RLC-92 x T-397) to 112.0 (Neela $\mathrm{x}$ Neelam). Out of twenty hybrids only three hybrids showed nonsignificant negative heterosis, eleven hybrids showed non-significant positive heterosis and six hybrid showed significant positive heterosis. The range of heterobeltiosis was observed from -27.4 (RLC-92 x Shekhar) to 91.4 (Sagar Local x T-397). Out of twenty crosses only two hybrids showed significant positive heterobeltiosis, five hybrid showed negative non-significant heterobeltiosis while remaining thirteen hybrid showed nonsignificant positive heterobeltiosis.

\section{Number of capsules plant ${ }^{-1}$}

Range of average heterosis varied from -20.7 (SagarLocal x Neelam) to 391.5 (SagarLocal xT-397). Seven hybrids out of twenty crosses showed significant positive heterosis for this trait. Whereas two hybrids showed nonsignificant negative heterosis and eleven hybrids showed non-significant positive heterosis. The range of heterobeltiosis for this character was from -44.5 (RLC-92 x Shekhar) to 382.4 (SagarLocal x T-397). Seven hybrids showing positive significant heterobeltiosis, four hybrids showed non-significant negative heterosis and remaining nine hybrids showed non-significant positive heterobeltiosis for number of capsules plant ${ }^{-1}$.

\section{Number of seeds capsule ${ }^{-1}$}

The magnitude of average heterosis for this trait ranged from -44.9 (RLC-92x T-397) to 9.7 (Sakoor x Chambal).Most of the hybrids showed negative heterosis except RLC-92 x Chambal, Sakoor x Chambal and SagarLocal $x$ Chambal, out of them only five hybrid showed significant negative heterosis for this trait. The heterobeltiosis ranged from -47.06 (RLC-92x T-397) to-4.26 (Sakoor X Chambal).All the hybrids showed negative heterobeltiosis out of them seven hybrids showed significant negative heterobeltiosis and remaining hybrids showed nonsignificant negative heterobeltiosis.

\section{Total number of branches plant ${ }^{-1}$}

The average heterosis for this trait ranged from 108.99 (SagarLocal $x$ T-397) to 1.05 (RLC-92 x Shekhar). All the hybrids showed positive average heterosis out of them eleven hybrids showed significant positive heterosis and remaining hybrids showed nonsignificant positive heterosis. The extent of heterobeltiosis ranged from -21.31 (RLC-92 x Shekhar) to 85.0 (Sabour Yellow x Chambal). All the hybrids except RLC-92 x T-397, RLC-92 x Shekhar and Sakoor x Chambal showed non-significant positive heterobeltiosis. None of the hybrids showed significant heterobeltiosis.

\section{0 seed weight $(g)$}

The magnitude of average heterosis for this character varied from -14.6 (Sagar Local x Neelam) to 28.9 (RLC-92 xT-397).Out of twenty crosses eleven hybrids showed nonsignificant negative heterosis and remaining hybrids showed non-significant positive hybrids. None of the hybrids showed significant for this character. The heterobeltiosis for this trait ranged from -22.6 (SagarLocal x Neelam) to 19.4 (RLC-92 x T- 
397). Only five hybrid out of twenty crosses showed non-significant positive heterobeltiosis and remaining hybrid exhibited non-significant negative hybrids.

\section{Seed yield plant $^{-1}(\mathrm{~g})$}

Seed yield is the main objective of any breeding programme and hence, significant positive heterotic crosses are desirable for this character. The magnitude of average heterosis for this character ranged from -37.6 (Sabour Yellow x Shekhar) to 60.9 (Neela x Neelam). Nine crosses exhibited non-significant negative heterosis out of twenty crosses and remaining crosses showed non-significant positive heterosis except the hybrid, Neela $x$ Neelam which showed significant positive heterosis. For this character heterobeltiosis ranged from -39.1 (SabourYellow x Shekhar) to 58.7 (Neela $x$ Neelam). Out of twenty hybrids ten hybrids showed non-significant negative heterosis and remaining hybrids showed non-significant positive heterosis. None of the hybrids showed significant heterobeltiosis for this character.

From the perusal of the data presented (Table 1). The best $F_{1}$ is Sabour Yellow x Chambal which shows superiority for multiple traits like days to 50\% flowering, plant height $(\mathrm{cm})$, number of primary branches plant ${ }^{-1}$, number of secondary branches ${ }^{-1}$, number of capsules plant $^{-1}$ (Table 2). The manifestation of heterosis as observed in the present study, is in harmony with the previous studies, wherein heterosis for seed yield plant ${ }^{-1}(\mathrm{~g})$ and its associated traits has been reported in different combination of parents (Kumar and Singh, 2002; Singh et al., 2005 and Ram Jeet et al., 2010). The study reveals good scope for commercial exploitation of heterosis and isolation of pure lines among the progenies of heterotic $F_{1}$ for improvement of yield levels in linseed. For enhancement of seed yield and its attributing traits, best heterotic crosses selected on the basis of present study are presented in (Table 2) Hence, the hybrids having high heterosis can be effectively used for isolating transgressive segregants, which will increase the frequency of desirable genes for yield component traits along with economic traits in linseed. These observations were in agreement with the findings of earlier workers, Many workers have reported high degree of heterosis in linseed viz., Rede, (1999), Kusalkar et al., (2002), Kumar and Singh (2002), Joshi, (2004), Singh et al., (2005), Ram Jeet et al., (2010), Kumar et al., (2013), Reddy et al., (2013), Pali and Mehta (2014a), Pali and Mehta (2014b) and Kumar and Paul (2015).

Assessing the heterotic effects in the crosses derived from genetically diverse parent, in terms of yield, its various attributing traits had been one of the objectives of the present study. It may be positive or negative in direction. Negative heterosis is desirable for earliness and dwarf types in linseed. Conventionally parents with higher mean value considered better parent for yield and its attributes, while parents with low mean value considered better parent for earliness. Thus, expected heterobeltiosis will be $F_{1}>P_{1}$ for yield and attributes (Table 3). Heterosis in negative direction is generally preferred for the characters like days to $50 \%$ flowering, days to maturity and plant height in linseed. Dwarf plants are considered as lodging resistance; therefore, negative heterosis in plant height is important. The results indicated that the crosses exhibited high heterotic effect for yield and its important attributes, might possibly be useful in heterosis breeding programmes for further improvement. These crosses with high heterotic effect also gave an idea to consider these heterotic effects for the production of superior lines. However, the isolation of superior lines may be difficult to isolate in small population of heterotic crosses in which 
the number of segregating loci with additive gene effect is relatively large. In such circumstances, it would be better to adopt the "Biparental cross approach" for the accumulation of favorable and additive gene effects for linseed improvement of Chhattisgarh plains (Pali and Mehta, 2014b). The results of the present study indicated that the crosses exhibited high heterotic effect for yield and its important attributes, might possibly be useful in heterosis breeding programmes for further improvement. It could be worth finding out whether superior crosses showing heterosis were also throwing out superior segregants.

\section{References}

Anonymous. 2014. Annual report linseed 201415. AICRP on Linseed, PC Unit Kanpur.

Jhajharia, S., Choudhary, P., Jhajharia, A., Meena, L.K. and Singh, D. 2013. Heterosis and combining ability in safflower (Carthamus tinctorius L.) germplasm lines. The Bioscan. 8(4): 1453-1460.

Joshi, P. K. 2004. Breeding behavior and association analysis for yield and yield component in linseed (Linum usitatissimum L.). Ph. D. Thesis, IGKV, Raipur, C.G.

Kempthorne, O. 1957. An Introduction to Genetic Statistics, New York, John Wiley and Sons, 1st Edn., pp. 456-471.

Kumar, S., Kerkhi, S.A., Kumar, A. and Singh, S.D. 2013. Combining ability and heterosis analysis in linseed (Linum usitatissimum L.). Ann. Agric. Res., 34 (3): 197-204.

Kumar, M. and Singh, P.K. 2002.Heterosis in linseed (Linum usitatissimum L.). Annals Agril Res., 23:506-508.

Kumar, N. and Paul, S. 2015. Genetic analysis of yield and yield contributing traits in linseed (Linum usitatissimum L.). The Bioscan, 10(4): 1951-1955.
Kusalkar, A.M., Patil, B.R., Thawari, S.B., Khatod, J.P. and Shivankar, R.S. 2002. Heterosis studies in linseed. J. Soils and Crops, 12(2): 196-198.

Pali, V. and Mehta, N. 2014a.Combining ability and heterosis for seed yield and it'sattributes in linseed (Linum usitatissimum L.) The Bioscan, 9(2): 701-706.

Pali, V. and Mehta, N. 2014b.Estimation of heterosis for seed yield and its attributing traits in linseed (Linum usitatissimum L.). Elec. J. Plant Breed., 5(1): 120-123.

Ram Jeet, Singh, P.K., Rama Kant and Vimal, S.C.2010. Assessment of heterosis in linseed (Linum usitatissimum L.). Agril. and Biol. Res., 26: 64-76.

Ramesh, M., Lavanya, C., Sujatha, M., Sivasankar, A., Aruna Kumari, J. and Meena, H. P. 2013. Heterosis and combining ability for yield and yield component characters of newly developed castor (Ricinus communis L.) hybrid. The Bioscan. 8(4): 1421-1424. Morris, D.H. 2005. Flax-a smart choice. New Flax Facts, Fax council of Canada.

Ratnaparkhi, R.D., Dudhe, M.Y., Gawande, N.D. and Bhongle, S.A. 2005.Combining ability study in linseed through line $\times$ tester analysis. Ann. Plant Physiol., 19(1): 99-102.

Reddy, M.P., Arsul, B.T., Shaik, N.R. and Maheshwari, J.J. 2013. Estimation of heterosis for some traits in linseed (Linum usitatissimum L.). J. Agri and Vet. Sci., 2(5): 11-17.

Rede, A.P. 1999. Genetic analysis of yield and yield attributing characters in linseed (Linum usitatissimum L.). M.Sc. Thesis, IGKV, Raipur, C.G.

Richharia, R.H. 1962. Linseed. The Indian Central Oilseeds Committee, Hyderabad, India: 155.

Sharma, R., Tiwari, S.K., Singh, P., Kant, Rama. 2005. Heterobeltiosis and 
inbreeding depression in linseed. Agril. Sci. Digest, 25(1): 35-37.

Singh, P., Singh, D. and Singh, S.K. 2005. Heterosis in relation to other genetic parameters in linseed. Farm Sci. J., 14:
$1-3$.

Vavilov, N.I. 1935. Studies on the origin of cultivated plants. Bull. Bot. Pl. Breed, 16: 39-145.

\section{How to cite this article:}

Namrata Dhirhi, Nandan Mehta and Satyapal Singh. 2018. Estimation of Heterosis for Seed Yield and Its Attributing Traits in Linseed (Linum usitatissimum L.). Int.J.Curr.Microbiol.App.Sci. 7(11): 2332-2341. doi: https://doi.org/10.20546/ijcmas.2018.711.263 